\title{
Osteology and Myology of the Cephalic Region and Pectoral Girdle of Pangasius macronema, With a Discussion on the Synapomorphies and Phylogenetic Relationships of the Pangasiidae (Teleostei: Siluriformes)
}

\author{
Osteología y Miología de la Región Cefálica y de la Cintura Pectoral del Pangasius macronema, con \\ una Discusión de las Sinapomorfías y Relaciones Filogenéticas de los Pangasiidae (Telostei; Siluriformes)
}

\author{
Rui Diogo
}

DIOGO, R. Osteology and myology of the cephalic region and pectoral girdle of Pangasius macronema, with a discussion on the synapomorphies and phylogenetic relationships of the Pangasiidae (Telostei: Siluriformes). Int. J. Morphol., 25(3):453-466, 2007.

SUMMARY: The cephalic and pectoral girdle structures of Pangasius macronema are described and compared with those of another representative of the same genus, Pangasius larnaudii, and of representatives of the other pangasiid genus, Helicophagus leptorhynchus and Helicophagus typus, as well as of several other catfishes, as the foundation for a discussion of the synapomorphies and phylogenetic relationships of the Pangasiidae. The following two features could constitute Pangasiidae autapomorphies: 1) presence of prominent crest on the dorso-lateral surfaces of both the hyomandibulo-metapterygoid and the ento-ectopterygoid; 2) presence of a large, circular foramen between the anterodorsomedial surface of the extrascapular, the dorsomesial surface of the pterotic and the dorsolateral surface of the parieto-supraoccipital. With respect to the phylogenetic relationships of the Pangasiidae, this family is seemingly closely related to the Schilbidae.

KEY WORDS: Catfish; Helicophagus; Pangasius; Pangasiidae synapomorphies; Morphology; Phylogeny, Siluriformes.

\section{INTRODUCTION}

The Siluriformes, with over 2750 species, constitute one of the most diverse Vertebrate taxa and are one of the economically important groups of fresh and brackish water fishes in the world (Teugels, 2003). Among the 35 siluriform families (Ferraris \& De Pinna, 1999), the Asian family Pangasiidae includes several species of great economic importance in fisheries and fishculture (Teugels). Roberts \& Vidthayanon (1991) recognised two pangasiid genera, with 21 species. However, recent taxonomic revisions have led to the description of numerous new pangasiid species (e.g. Pouyaud et al., 1999, 2000; Pouyaud \& Teugels, 2000; Ng \& Kottelat, 2000; Gustiano et al., 2003). In the most recent overview of siluriform systematics, Teugels recognised two pangasiid genera, Helicophagus and Pangasius, with 3 and 25 species, respectively.

Despite the large number of studies on catfish anatomy (e.g. McMurrich, 1884; Regan 1911; Gauba, 1962, 1966,
1967, 1968, 1969; Tilak, 1963a,b, 1964; Alexander, 1965; Chardon, 1968; Gosline, 1975; Howes, 1983a,b, 1985; Mo 1991; Diogo \& Chardon, 2000a,b,c; Diogo et al. 1999, 2000a,b, 20001a,b,c, 2002ab), the only papers published so far in which the morphology of pangasiids is described with some detail are those of Bhimachar (1933), Tilak (1963b, 1964) and Chardon. Moreover, as these descriptions are almost exclusively restricted to the osteology and external anatomy, some important morphological aspects of these fishes, such as the configuration of the cephalic muscles, of the structures associated with the mandibular barbels, and of the pectoral girdle musculature, are practically unknown. As stressed by Diogo (2003) and Teugels (2003), although the family Pangasiidae is commonly considered as monophyletic (e.g. Regan; Chardon; Mo), no reliable pangasiid autapomorphies have been proposed in studies published so far. 
The aim of this work is to describe the osteological and myological structures of the cephalic region (branchial apparatus excluded) and pectoral girdle of a species belonging to the type genus of the Pangasiidae, Pangasius macronema and to compare these structures with those of another representative of that genus, Pangasius larnaudii and of representatives of the other pangasiid genus, Helicophagus leptorhynchus and Helicophagus typus, as well as of several other catfishes, as the foundation for a discussion on the synapomorphies and phylogenetic relationships of the Pangasiidae. It is hoped that this study will increase the knowledge of the anatomy and phylogeny of the catfishes in general, as well as pave the way for future works concerning the comparative anatomy, phylogeny, evolution, and functional morphology of these fishes.

\section{MATERIAL AND METHOD}

The specimens studied are from the Laboratory of Functional and Evolutionary Morphology (LFEM), from the Musée Royal de l'Afrique Centrale of Tervuren (MRAC), from the Université Nationale du Bénin (UNB), from the Muséum National d'Histoire Naturelle of Paris (MNHN), from the National Museum of Natural History of Washington (USNM), and from the South African Institute for Aquatic Biodiversity (SAIAB) and the Albany Museum of Grahamstown (AMG). Anatomical descriptions are made after dissection of alcohol-preserved or trypsincleared and alizarine-stained (following Taylor and Van Dyke's 1985 method) specimens. Dissections and morphological drawings were made using a Wild M5 dissecting microscope equipped with a camera lucida. The alcohol fixed (alc), trypsin-cleared and alizarine-stained (c\&s), or simply alizarine-stained (s) condition of the studied fishes is given in parentheses following the number of specimens dissected. A list of the specimens dissected is given below.

Akysidae: Akysis baramensis LFEM, 2 (alc). Akysis leucorhynchus USNM 109636, 2 (alc). Parakysis anomalopteryx USNM 230307, 2 (alc); LFEM, 1 (alc).

Amblycipitidae: Amblyceps caecutiens LFEM, 2 (alc). Amblyceps mangois USNM 109634, 2 (alc). Liobagrus reini USNM 089370, 2 (alc).

Amphiliidae: Amphilius brevis MRAC 89-043-P-403, 3 (alc); MRAC 89-043-P-2333, 1 (c\&s). Andersonia leptura MNHN 1961-0600, 2 (alc). Belonoglanis tenuis MRAC P.60494, 2 (alc). Doumea typica MRAC 93-041-P-1335, 1 (alc). Leptoglanis rotundiceps MRAC P.186591-93, 3 (alc). Paramphilius trichomycteroides LFEM, 2 (alc). Phractura brevicauda MRAC
90-057-P-5145, 2 (alc); MRAC 92-125-P-386, 1 (c\&s). Phractura intermedia MRAC 73-016-P-5888, 1 (alc). Trachyglanis ineac MRAC P.125552-125553, 2 (alc). Zaireichthys zonatus MRAC 89-043-P-2243-2245, 3 (alc).

Ariidae: Arius hertzbergii LFEM, 1 (alc). Arius heudelotii LFEM, 4 (alc). Bagre marinus LFEM, 1 (alc); LFEM, 1 (c\&s). Genidens genidens LFEM, 2 (alc).

Aspredinidae: Aspredo aspredo USNM 226072, 1 (alc). Aspredo sicuephorus LFEM, 1 (alc). Bunocephalus knerii USNM 177206, 2 (alc). Xyliphius magdalenae USNM 120224, 1 (alc).

Astroblepidae: Astroblepus phelpis LFEM, 1 (alc); USNM 121127, 2 (alc).

Auchenipteridae: Ageneiosus vittatus USNM 257562, 1 (alc). Auchenipterus dentatus USNM 339222, 1 (alc). Centromochlus hechelii USNM 261397, 1 (alc).

Austroglanididae: Austroglanis gilli LFEM, 3 (alc); SAIAB 58416 (c\&s). Austroglanis sclateri AMG, 1 (c\&s); SAIAB $68917(\mathrm{~s})$.

Bagridae: Bagrichthys macropterus USNM 230275, 1 (alc). Bagrus bayad LFEM, 1 (alc); LFEM, 1 (c\&s). Bagrus docmak MRAC 86-07-P-512, 1 (alc); MRAC 86-07-P-516, 1 (c\&s). Hemibagrus nemurus USNM 317590, 1 (alc). Rita chrysea USNM 114948, 1 (alc).

Callichthyidae: Callichthys callichthys USNM 226210, 2 (alc). Corydoras guianensis LFEM, 2 (alc).

Cetopsidae: Cetopsis coecutiens USNM 265628, 2 (alc). Helogenes marmoratus USNM 264030, 1 (alc). Hemicetopsis candiru USNM 167854, 1 (alc).

Chacidae: Chaca bankanensis LFEM, 3 (alc). Chaca burmensis LFEM, 2 (alc). Chaca chaca LFEM, 2 (alc).

Clariidae: Clarias anguillaris LFEM, 2 (alc). Clarias batrachus LFEM, 2 (alc). Clarias ebriensis LFEM, 2 (alc). Clarias gariepinus MRAC 93-152-P-1356, 1 (alc), LFEM, 2 (alc). Heterobranchus bidorsalis LFEM, 2 (alc). Heterobranchus longifilis LFEM, 2 (alc). Uegitglanis zammaronoi MRAC P15361, 1 (alc).

Claroteidae: Auchenoglanis biscutatus MRAC 73-015-P999, 2 (alc). Auchenoglanis occidentalis LFEM, 2 (alc). Chrysichthys auratus UNB, 2 (alc); UNB, 2 (c\&s). Chrysichthys nigrodigitatus $\mathrm{UNB}, 2$ (alc); UNB, 2 (c\&s). Clarotes laticeps MRAC 73-13-P-980, 2 (alc).

Cranoglanididae: Cranoglanis bouderius LFEM, 2 (alc).

Diplomystidae: Diplomystes chilensis LFEM, 3 (alc).

Doradidae: Acanthodoras cataphractus USNM 034433 , 2 (alc). Anadoras weddellii USNM 317965, 2 (alc). Doras brevis 
DIOGO, R. Osteology and myology of the cephalic region and pectoral girdle of Pangasius macronema, with a discussion on the synapomorphies and phylogenetic relationships of the Pangasiidae (Telostei: Siluriformes). Int. J. Morphol., 25(3):453-466, 2007.

LFEM, 2 (alc). Doras punctatus USNM 284575, 2 (alc). Franciscodoras marmoratus USNM 196712, 2 (alc).

Erethistidae: Erethistes pusillus USNM 044759, 2 (alc). Hara filamentosa USNM 288437, 1 (alc).

Heteropneustidae: Heteropneustes fossilis USNM 343564 , 2 (alc); USNM 274063, 1 (alc); LFEM, 2 (alc).

Ictaluridae: Amiurus nebulosus USNM 246143, 1 (alc); USNM 73712, 1 (alc). Ictalurus furcatus LFEM, 2 (alc). Ictalurus punctatus USNM 244950, 2 (alc).

Loricariidae: Hypoptopoma bilobatum LFEM, 2 (alc). Hypoptopoma inexspectata LFEM, 2 (alc). Lithoxus lithoides LFEM, 2 (alc). Loricaria cataphracta LFEM, 1 (alc). Loricaria loricaria USNM 305366, 2 (alc); USNM 314311, 1 (alc).

Malapteruridae: Malapterurus electricus LFEM, 5 (alc).

Mochokidae: Mochokus niloticus MRAC P.119413, 1 (alc); MRAC P.119415, 1 (alc). Synodontis clarias USNM 229790, 1 (alc). Synodontis schall LFEM, 2 (alc). Synodontis sorex LFEM, 2 (alc).

Nematogenyidae: Nematogenys inermis USNM 084346, 2 (alc); LFEM, 2 (alc).

Pangasiidae: Helicophagus leptorhynchus USNM 355238, 2 (alc); LFEM, 4 (alc). Helicophagus typus LFEM, 3 (alc). Pangasius larnaudii USNM 288673, 1 (alc); LFEM, 5 (alc). Pangasius macronema USNM 316837, 2 (alc); LFEM, 3 (alc).

Pimelodidae: Batrochoglanis raninus USNM 226136, 3 (alc). Calophysus macropterus USNM 306962, 1 (alc); LFEM, 1 (alc). Goeldiella eques USNM 066180, 2 (alc). Heptapterus mustelinus USNM 287058, 2 (alc). Hypophthalmus edentatus USNM 226140, 1 (alc); LFEM, 1 (alc). Microglanis cottoides USNM 285838, 2 (alc). Pimelodus blochii LFEM, 2 (alc). Pseudoplatystoma fasciatum USNM 284814, 2 (alc). Rhamdia guatemalensis USNM 114494, 2 (alc).

Plotosidae: Cnidoglanis macrocephalus USNM 219580, 2 (alc). Neosilurus rendahli USNM 173554, 2 (alc). Paraplotosus albilabris USNM 173554, 2 (alc). Plotosus anguillaris LFEM, 2(alc). Plotosus lineatus USNM 200226), 2 (alc).

Schilbidae: Ailia colia USNM 165080, 1 (alc). Laides hexanema USNM 316734, 1 (alc). Pseudeutropius brachypopterus USNM 230301, 1 (alc). Schilbe intermedius MRAC P.58661, 1 (alc). Schilbe mystus LFEM, 3 (alc). Siluranodon auritus USNM 061302, 2 (alc).

Scoloplacidae: Scoloplax distolothrix LFEM, 1 (alc); USNM 232408, 1 (alc).

Siluridae: Silurus aristotelis LFEM, 2( alc). Silurus glanis LFEM, 2 (alc). Silurus asotus USNM 130504, 2 (alc). Wallago attu USNM 304884, 1 (alc).
Sisoridae: Bagarius yarreli USNM 348830, 2 (alc); LFEM, 1 (c\&s). Gagata cenia USNM 109610, 2 (alc). Glyptosternon reticulatum USNM 165114, 1 (alc). Glyptothorax fukiensis USNM 087613, 2 (alc).

Trichomycteridae: Hatcheria macraei LFEM, 2 (alc). Trichomycterus areolatus LFEM, 2 (alc). Trichomycterus banneaui LFEM, 2 (alc). Trichomycterus immaculatus USNM 301015, 2 (alc).

\section{RESULTS}

In the anatomical descriptions given in this Section, the nomenclature for the osteological structures of the cephalic region follows that used in recent papers by the author and colleagues (e.g. Diogo et al., 2004a,b,c). It should be noted that, for the several reasons explained in Diogo et al. (2001a) and Diogo \& Chardon (2003), with respect to the controversial nomenclature of the skeletal components of the suspensorium, Diogo et al. (2001a) is followed. The myological nomenclature is based on Diogo \& Vandewalle (2003). Concerning the nomenclature of the pectoral girdle bones and muscles, Diogo et al. (2001b) is followed.

\section{Pangasius macronema}

\section{Osteology}

Os mesethmoideum. It is situated on the antero-dorsal surface of the neurocranium (Fig. 1). Each of its welldeveloped antero-lateral arms is ligamentously connected to the premaxilla. Dorsomesially, the mesethmoid exhibits a large, deep concavity.

Os lateroethmoideum. Well-developed bone (Fig. 1), which exhibits a laterally directed articulatory facet for the autopalatine. There is a well-developed, roughly oval foramen between the postero-dorso-mesial surface of the lateral ethmoid and the antero-dorsal surface of the frontal.

Os praevomerale. T-shaped bony plate (Fig. 2) lying underneath the ethmoideal region and exhibiting two welldeveloped, posterolaterally directed antero-lateral arms. Each of these antero-lateral arms bears, ventrally, a well-developed tooth-plate.

Os orbitosphenoideum. Posterior to the lateral ethmoid (Figs. 1 and 2), with the dorsal edge of its lateral wall being sutured to the ventral surface of the frontal.

Os pterosphenoideum. It is posterior to the orbitosphenoid (Fig. 1), covering, together with that bone, the gap between the frontals and the parasphenoid. 
Os parasphenoideum. The parasphenoid (Fig. 2) is the longest bone of the cranium. It bears a pair of salient ascending flanges, which suture with the pterosphenoids and prootics.

Os frontale. The frontals (Fig. 1) are large, roughly rectangular bones that are largely separated by both the anterior and the posterior fontanels.

Os sphenoticum. This bone (Fig. 1) bears, together with the pterotic, a well-developed, elongated articulatory facet for the hyomandibulo-metapterygoid.

Os pteroticum. Posterior to the sphenotic and significantly larger than this latter bone (Fig. 1). There is a well-developed, roughly circular foramen between the dorsomesial surface of the pterotic, the dorsomedial surface of the parieto-supraoccipital and the anterodorsal margin of the extrascapular (Fig. 1).
Os prooticum. Together with the pterosphenoid, it borders the well-developed foramen of the trigemino-facial nerve complex.

Os epioccipitale. Small bone situated on the posterodorsal surface of the neurocranium.

Os exoccipitale. The exoccipital is a small bone situated laterally to the basioccipital and ventrally to the epioccipital.

Os basioccipitale. Well-developed, unpaired bone, which forms the posteriormost part of the floor of the neurocranium. Its ventro-lateral surfaces are firmly sutured to the ventro-medial limbs of the posttemporo-supracleithra.

Os parieto-supraoccipitale. The parietosupraoccipital (Fig. 1) is a large, unpaired bone with a welldeveloped, posteriorly directed postero-dorsal process.

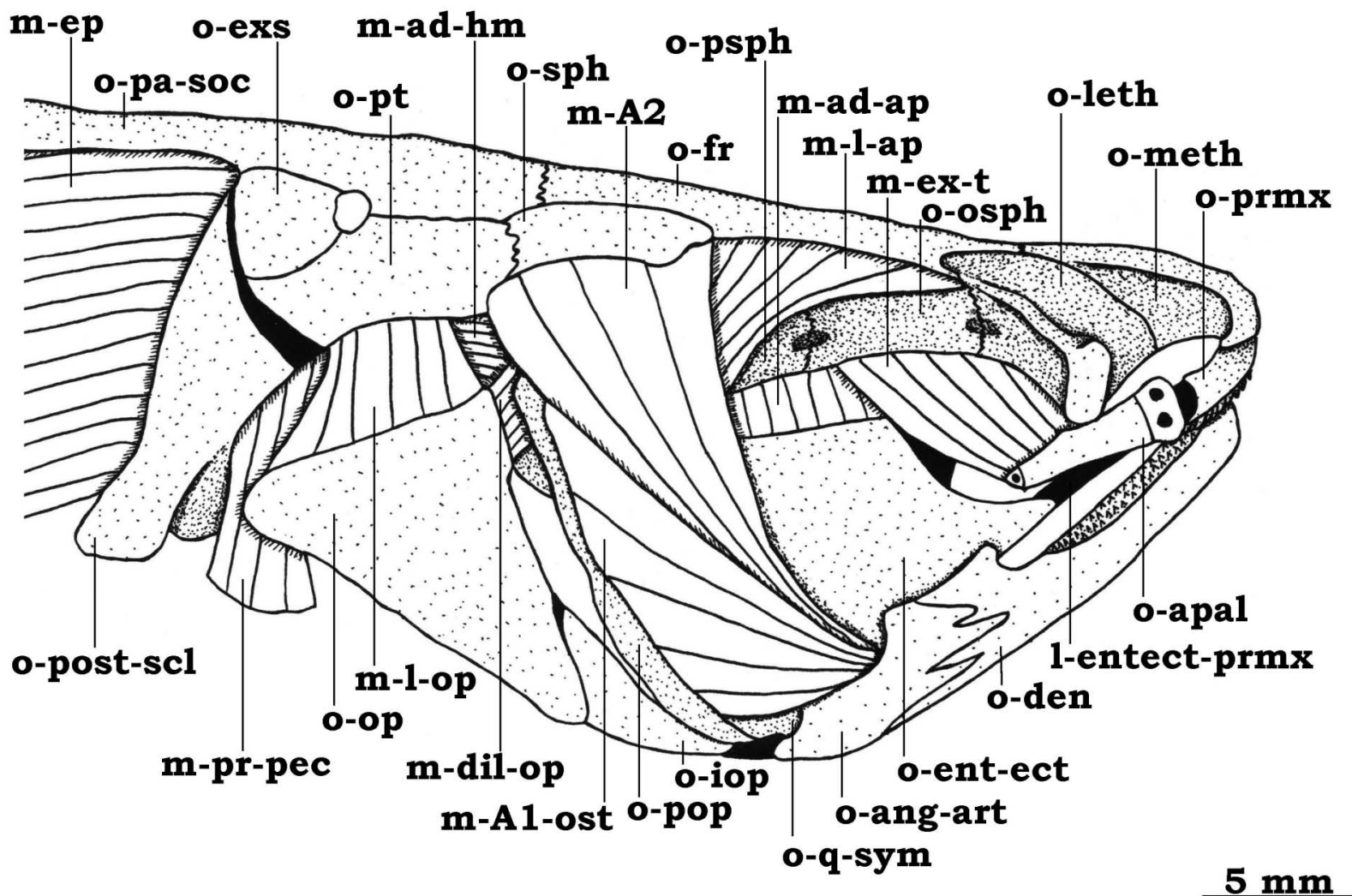

Fig. 1. Right, lateral view of the cephalic musculature of Pangasius macronema. All muscles are exposed; the maxilla was removed. 1entect-prmx ligamentum entoectopterygoideo-praemaxillare, $\mathrm{m}$-A1-ost m-A2 sections of the musculus adductor mandibulae, m-ad-ap musculus adductor arcus palatini, m-ad-hm musculus adductor hyomandibularis, m-dil-op musculus dilatator operculi, m-ep musculus epaxialis, m-ex-t musculus extensor tentaculi, m-l-ap musculus levator arcus palatini, m-l-op musculus levator operculi, m-pr-pec musculus protractor pectoralis, o-ang-art os angulo-articulare, o-apal os autopalatinum, o-den os dentale, o-ent-ect os ento-ectopterygoideum, oexs os extrascapulare, o-fr os frontale, o-iop os interoperculare, o-leth os latero-ethmoideum, o-meth os mesethmoideum, o-op os operculare, o-osph os orbitosphenoideum, o-pa-soc os parieto-supraoccipitale, o-pop os praeoperculare, o-post-scl os posttemporo-supracleithrum, o-prmx os praemaxillare, o-psph os pterosphenoideum, o-pt os pteroticum, o-q-sym os quadrato-symplecticum, o-sph os sphenoticum. 
Os extrascapulare. Small bone (Fig. 1) situated on the postero-dorso-lateral surface of the neurocranium, between the pterotic, the parieto-supraoccipital and the posttemporo-supracleithrum.

Os praemaxillare. The premaxillaries (Figs. 1 and 2) are a pair of large plates lying underneath and attaching to the mesethmoidal cornua via ligamentous tissue. Ventrally, each premaxilla bears numerous small teeth (Fig. 2) having their tips slightly turned backward.

Os maxillare. The maxillaries are markedly elongated proximo-distally (Fig. 2). The proximal tips of the maxillaries are connected to the premaxillaries by means of a short ligament. As in most catfishes, the maxillary barbels are supported by the maxillaries.

Os autopalatinum. Rod-like bone (Figs. 1 and 2) with the anterior end tipped by a well-developed cartilage that accepts the two proximal heads of the maxilla. Its posterior tip is capped by a small cartilage. Medially, the autopalatine articulates with the lateral ethmoid.
Os hyomandibulo-metapterygoideum. The homology, and, thus, the correct denomination, of this bone, as well as of the other suspensorium elements of the catfishes, has been the subject of endless controversies (for recent discussions on the subject, see e.g. Diogo et al., 2001a; Diogo \& Chardon, 2003). As referred before, the nomenclature used here to describe these elements will follow that presented by Diogo et al. (2001a). The hyomandibulo-metapterygoid (Fig. 3) is a large bone articulating dorsally with both the pterotic and the sphenotic and posteriorly with the opercle.

Os sesamoideum 1 of the suspensorium. Small, roughly triangular bone (Fig. 2) attached, by means of two thick ligaments, to the ento-ectopterygoid posteriorly and to the prevomer anteriorly, respectively (Fig. 2). Its antero-dorso-mesial surface is attached, via connective tissue, to the ventral surface of the lateral ethmoid and its dorso-lateral surface is attached, also via connective tissue, to the ventral surface of the autopalatine. The sesamoid bones 2 and 3 (see Diogo et al., 2001a) are absent, but there is a well-developed, roughly oval tooth-plate (Fig. 2) situated ventrally to, and firmly embedded in, a strong ligament running from the ento-

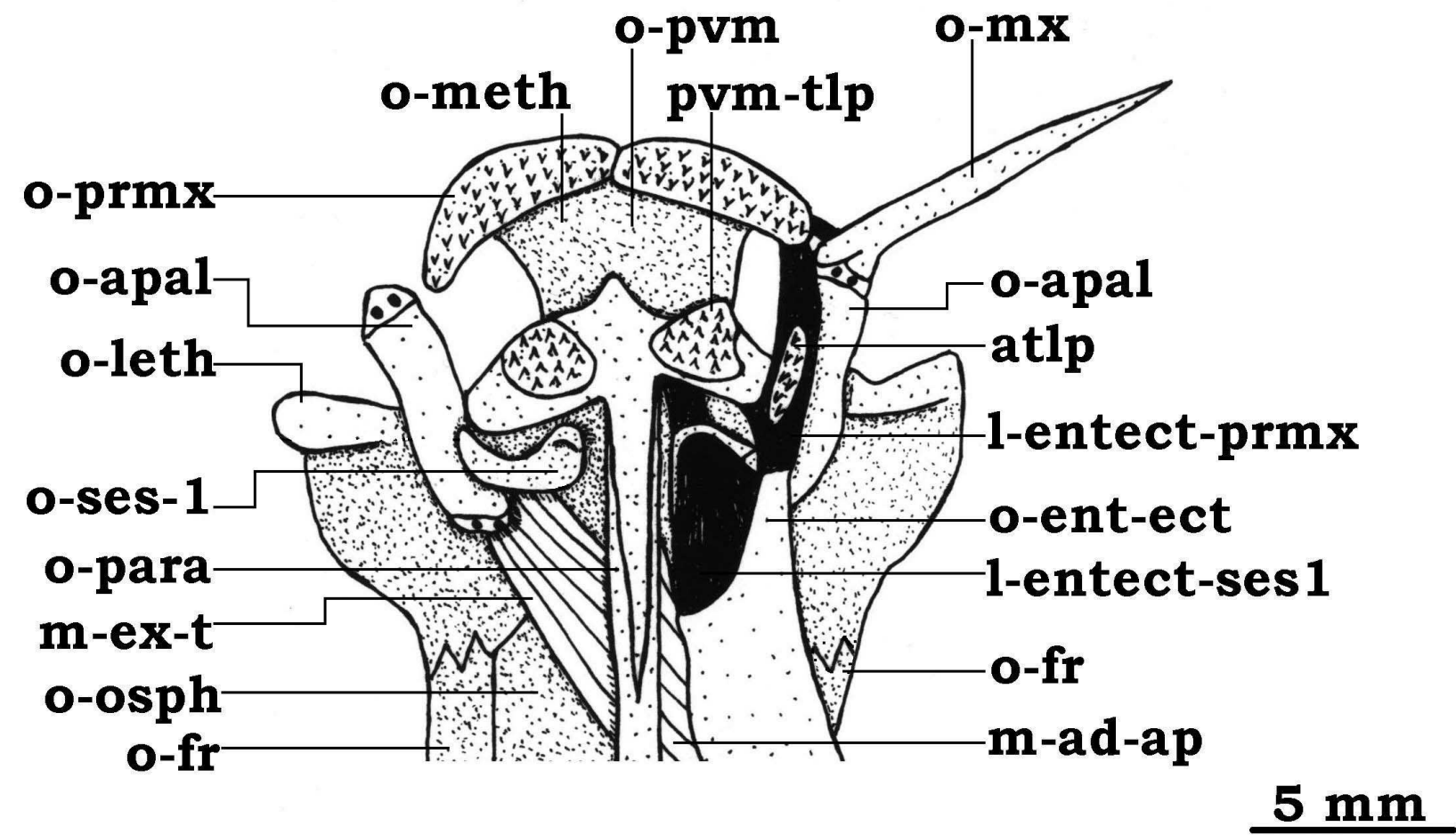

Fig. 2. Ventral view of the anterior region of the neurocranium, the suspensorium and the palatine-maxillary system of Pangasius macronema. On the left side the maxilla, the ento-ectopterygoid and the adductor arcus palatini, as well as the ligaments associated with both the suspensorium and the palatine-maxillary system, were removed. atlp additional tooth-plate, l-entect-prmx ligamentum entoectopterygoideopraemaxillare, l-entect-ses 1 ligamentum entoectopterygoideo-sesamoideum 1, m-ad-ap musculus adductor arcus palatini, m-ex-t musculus extensor tentaculi, o-apal os autopalatinum, o-ent-ect os ento-ectopterygoideum, o-fr os frontale, o-leth os lateralethmoideum, o-meth os mesethmoideum, o-mx os maxillare, o-osph os orbitosphenoideum, o-para os parasphenoideum, o-prmx os praemaxillare, o-pvm os praevomerale, o-ses-1 os sesamoideum 1, pvm-tlp prevomeral tooth-plate. 


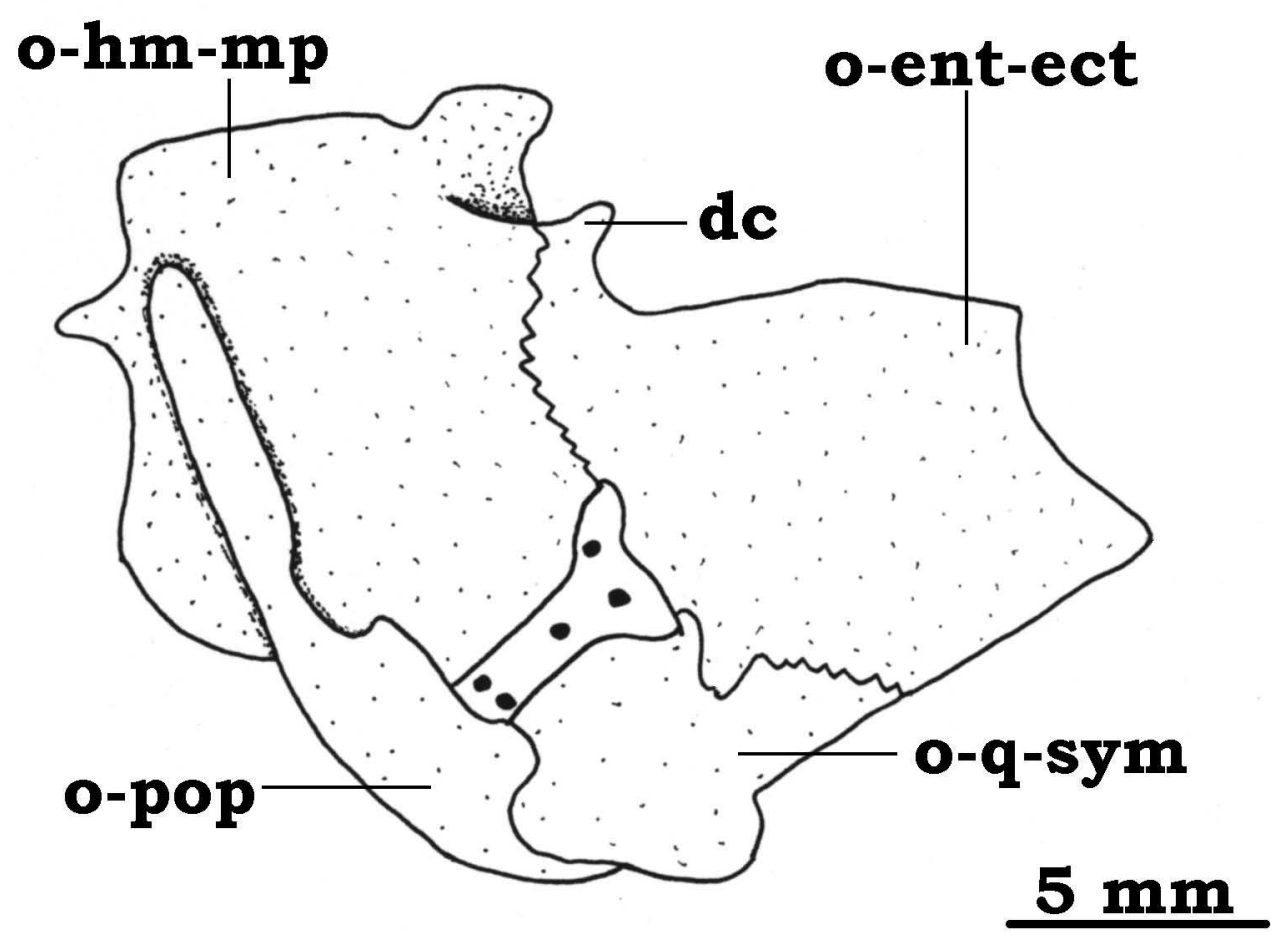

Fig. 3. Lateral view of the right suspensorium of Pangasius macronema. dc dorsal crest, o-ent-ect os ento-ectopterygoideum, o-hm-mp os hyomandibulo-metapterygoideum, o-pop os praeoperculare, o-q-sym os quadrato-symplecticum.

ectopterygoid to the premaxilla, which also contacts the lateral surface of the prevomer.

Os entopterygoido-ectopterygoideum. Welldeveloped, large bone (Figs. 1, 2 and 3) situated anteriorly to the hyomandibulo-metapterygoid and antero-dorsally to the quadrato-symplectic. Its anterior surface is slightly bifurcated. There is a well-developed, prominent, elongated dorsal crest formed by the dorso-lateral surfaces of both the ento-ectopterygoid and the hyomandibulo-metapterygoid (Fig 3: dc) in which inserts the muscle levator arcus palatini.

Os quadrato-symplecticum. The quadrato-symplectic (Figs. 1 and 3) exhibits a well-developed anterior articulatory surface to articulate with the postero-dorsal surface of the angulo-articular.

Os praeoperculare. This is a long and thin bone (Figs. 1 and 3 ) firmly sutured to both the hyomandibulometapterygoid and to the quadrato-symplectic.

Os operculare. Triangular bone (Fig. 1), anterodorsally articulating with the hyomandibulo-metapterygoid and antero-ventrally firmly connected, via connective tissue, with the interopercle.

Os interoperculare. Its anterior and antero-medial surfaces are ligamentously connected to the angulo-articular (Fig. 1) and to the posterior ceratohyal, respectively.

Os interhyale. The interhyal is well-developed. It is L-shaped and is attached, by means of strong ligaments, to both the posterior ceratohyal and the hyomandibulometapterygoid.

Os ceratohyale posterior. This triangular bone is linked by ligaments to the angulo-articular, interhyal and interopercle.

Os ceratohyale anterior. Situated between the ventral hypohyal and the posterior ceratohyal, it supports, together with this latter bone, the branchiostegal rays.

Os hypohyale ventrale. Each ventral hypohyal contains a deep ventral concavity to receive one of the anterolateral edges of the parurohyal.

Os hypohyale dorsale. Small bone situated dorsally to the ventral hypohyal.

Os parurohyale. The parurohyal is a well-developed bone with two postero-lateral arms and a large postero-mesial process. It lies medially behind the ventro-medial surfaces of the ventral hypohyals and is connected to these latter bones by means of two strong, thick ligaments. 


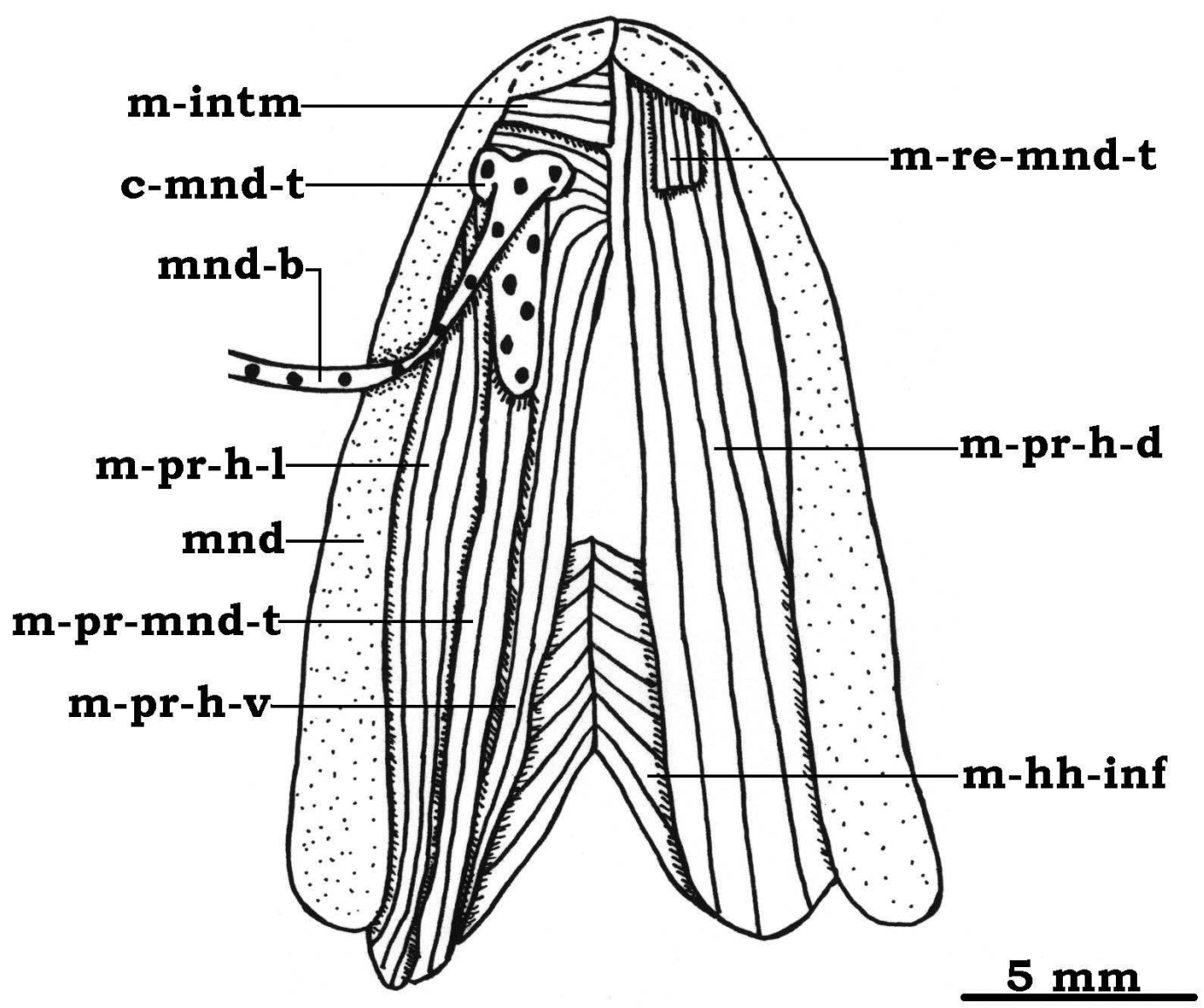

Fig. 4. Ventral view of the hyoid musculature of Pangasius macronema. On the left side all the musculature is exposed; on the right side the intermandibularis, the ventral and lateral parts of the protractor hyoidei and the protractor mandibularis tentaculi, as well as the mandibular barbel and its respective cartilage, were removed. c-mnd-t cartilago mandibularis tentaculi, mnd-b mandibular barbel, m-hhinf musculus hyohyoideus inferior, m-intm musculus intermandibularis, mnd mandible, m-pr-mnd-t musculus protractor mandibularis tentaculi, m-pr-h-d, m-pr-h-l, m-pr-h-v pars dorsalis lateralis and ventralis of musculus protactor hyoideus, m-re-mnd-t musculus retractor mandibularis tentaculi.

Os angulo-articulare. This bone (Fig. 1), together with the dentary bone, coronomeckelian and Meckel's cartilage, constitute the mandible. Its antero-dorsal surface, together with the postero-dorsal surface of the dentary bone, form a markedly elongated coronoid process (Fig. 1). Postero-dorsally, the angulo-articular has an articulatory surface for the quadrato-symplectic. Postero-ventrally, it exhibits a well-developed, posteriorly directed posteromedial process that is ligamentously connected to the interopercle (Fig. 1).

Os dentale. The dentaries (Fig. 1) are large bones firmly connected antero-mesially by strong connective tissue. Antero-dorsally, they bear numerous small, roughly conical teeth (Fig. 1). The dentaries exhibit two well-developed, large antero-ventro-mesial laminar extensions, which situate ventrally to the intermandibularis muscle and cover a great part of this muscle in a ventral view (Fig. 4).
Os coronomeckelium. This is a small bone lodged in the medial surface of the mandible. Postero-dorsally it bears a crest for attachment of the adductor mandibulae A3'.

Os posttemporo-supracleithrum. The dorso-medial limb of this well-developed bone (Fig. 1) is attached, by strong connective tissue, to both the pterotic and the extrascapular. Its stout ventro-medial limb is firmly attached to the basiocccipital. Its ventro-lateral limb is deeply forked, forming an articulating groove for the upper edge of the cleithrum. The posteroventral surface of the posttemporosupracleithrum is weakly attached, by means of connective tissue, to the anteroventral process of the fourth parapophysis (Müllerian process), which is well-developed and exhibits a highly mobile, oval ventrolateral tip. This highly mobile Müllerian process, together with a well-developed, separate muscle, the protractor of the Müllerian process, running from its anterior surface to the posterior surface of the 
neurocranium, form an 'elastic-spring-apparatus' (see e.g. Bridge \& Haddon, 1894; Alexander; Chardon).

Os cleithrum. The cleithrum (Fig. 5) is a large, wellossified stout structure forming a great part of the pectoral girdle and the posterior boundary of the branchial chamber. It bears a deep crescentic, medially faced groove, with rough surfaces, which accommodates the thick crescentic dorsal condyle of the pectoral spine. The two cleithra are firmly attached in the antero-medial line via connective tissue. The humeral process (Fig. 5: o-cl-hp) is well-developed.

Os scapulo-coracoideum. This is an elongated bony plate suturing with the cleithrum along its antero-lateral edge (Fig. 5). Antero-laterally, it exhibits a large anteriorly directed process, usually called the coracoid bridge (Fig. 5: cor-bri), which extends ventrally to the ventro-lateral surface of the cleithrum, suturing with an antero-ventral ridge of this bone. Mesially, the scapulo-coracoid joins its counterpart in an interdigitation of several strong serrations. Postero-laterally, it bears two condyles, which articulate, respectively, with the pectoral spine and the complex radial (see Mo). Its posterior surface is pierced by a well-developed foramen, which accepts the anterior condyle of the pectoral spine when this latter is abducted. There is a well-developed mesocoracoid arch.

\section{Myology}

Musculus adductor mandibulae. The adductor mandibulae A1-ost (Fig. 1) originates on the preopercle, quadrato-symplectic and hyomandibulo-metapterygoid and inserts on the latero-dorsal surface of the angulo-articular. The A2 (Fig. 1), which lies dorso-mesially to the A1-ost, originates on the preopercle, hyomandibulo-metapterygoid, pterotic and sphenotic, and inserts on the mesial surface of the angulo-articular. The adductor mandibulae A3' runs from the hyomandibulo-metapterygoid, ento-ectopterygoid and quadrato-symplectic to the coronomeckelian bone. Lastly, the Aw, which is well-developed, attaches anteriorly on the mesial surface of both the dentary bone and the angulo-articular and posteriorly on the tendon of the A2. The adductor mandibulae A3" (see Diogo \& Chardon, 2000b) is missing.

Musculus levator arcus palatini. The levator arcus palatini (Fig. 1) originates on the lateral ethmoid, orbitosphenoid, pterosphenoid, frontal and sphenotic and inserts on the lateral face of both the hyomandibulometapterygoid and the ento-ectopterygoid.

Musculus adductor arcus palatini. Well-developed muscle (Figs. 1 and 2), extending from the lateral sides of the parasphenoid, pterosphenoid and orbitosphenoid to the medial sides of the hyomandibulo-metapterygoid and entoectopterygoid.

Musculus levator operculi. It originates on the ventrolateral margin of the pterotic and inserts on the dorsal edge of the opercle (Fig. 1).

Musculus adductor hyomandibularis. Small muscle situated mesially to the levator operculi and laterally to the adductor operculi (Fig. 1). It originates on the ventral surface of the pterotic and inserts on the postero-dorso-lateral surface of the hyomandibulo-metapterygoid.

Musculus adductor operculi. Well-developed muscle running from the ventral surface of the pterotic to the dorsomesial surface of the opercle.

Musculus dilatator operculi. Situated medially to the levator arcus palatini, it runs from the pterotic, sphenotic, frontal, orbitosphenoid and hyomandibulo-metapterygoid to the antero-dorsal edge of the opercle (Fig. 1) (medial to the preopercle but lateral to the articulatory facet of the opercle for the hyomandibulo-metapterygoid).

Musculus extensor tentaculi. Well-developed (Figs. 1 and 2), it originates on the lateral ethmoid, orbitosphenoid and parasphenoid and inserts on the posteromesial margin of the autopalatine.

Musculus protractor hyoidei. This muscle has 3 parts (Fig. 4). The pars lateralis (Fig. 4: m-pr-h-1) originates on both the anterior and the posterior ceratohyal and inserts on the ventro-medial face of the dentary bone. The pars ventralis (Fig. 4: m-pr-h-v), in which are lodged the large, anteriorly bifurcated cartilages associated with the mandibular barbels (Fig. 4), originates on the anterior ceratohyal and inserts on the dentary bone, meeting its counterpart in a well-developed median aponeurosis. Lastly, the pars dorsalis (Fig. 4: m-prh-d) runs from the anterior ceratohyal to the antero-mesial surface of the dentary bone.

Muscle intermandibularis. Well-developed muscle joining the two mandibles (Fig. 4).

Musculus protractor mandibularis tentaculi. Welldeveloped, elongated muscle (Fig. 4) running from the anterior ceratohyal to the moving part (see Diogo and Chardon 2000c) of the cartilage associated with the mandibular barbel.

Musculus retractor mandibularis tentaculi. This muscle (Fig. 4) runs from the dentary bone to the moving part of the cartilage associated with the mandibular barbel. 
Musculus hyohyoideus abductor. It runs from the first (medial) branchiostegal ray to a median aponeurosis, which is associated with two long, strong tendons, attached, respectively, to the two ventral hypohyals.

Musculus hyohyoideus adductor. Each hyohyoideus adductor connects the branchiostegal rays of the respective side, as well as the most external branchiostegal ray and the opercle of that side.

Musculus hyohyoideus inferior. This thick muscle (Fig. 4) attaches medially on a median aponeurosis and laterally on the ventral surfaces of the ventral hypohyal, anterior ceratohyal and posterior ceratohyal.
Musculus sternohyoideus. It runs from the anterior region of the cleithrum to the posterior region of the parurohyal.

Musculus arrector ventralis. It originates on the ventral surface of the cleithrum and inserts on the ventral condyle of the pectoral spine (Fig. 5).

Musculus arrector dorsalis. It is differentiated into two well-developed divisions. The ventral division, situated on the ventral surface of the pectoral girdle (Fig. 5: m-arr-d$\mathrm{vd)}$, originates on the ventral margin of both the cleithrum and the scapulo-coracoid and inserts on the antero-lateral edge of the pectoral spine. The dorsal division, situated on

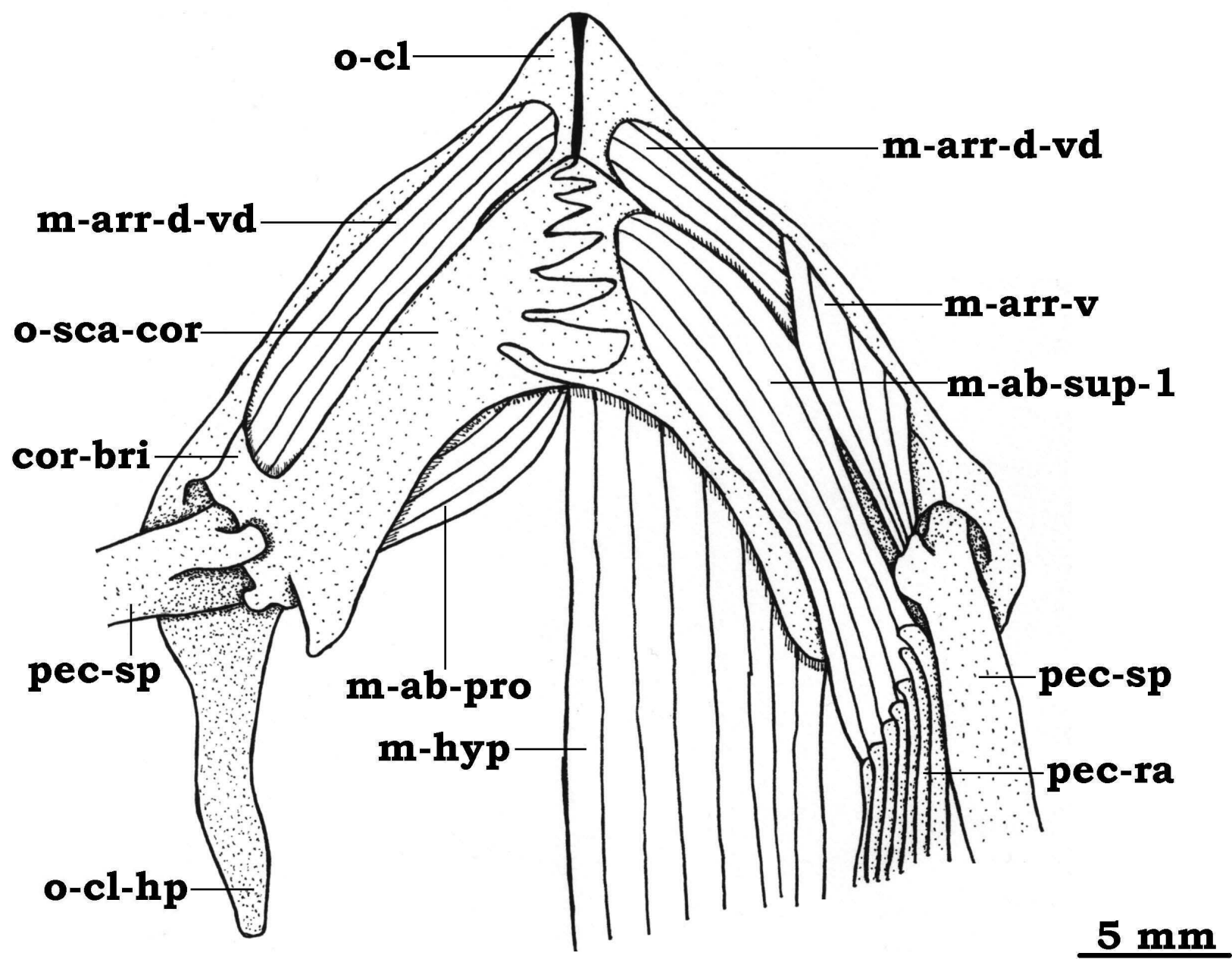

Fig. 5- Ventral view of the pectoral girdle of Pangasius macronema. On the right side all the musculature is exposed; on the left side the abductor superficialis, arrector ventralis and hypaxialis, as well as the pectoral rays, were removed. cor-bri coracoid bridge, m-ab-pro musculus abductor profundus, m-ab-sup- 1 section of musculus abductor superficialis, $\mathrm{m}$-arr-d-vd ventral division of musculus arrector dorsalis, m-arr-v musculus arrector ventralis, m-hyp musculus hypaxialis, o-cl os cleithrum, o-cl-hp humeral process of os cleithrum, osca-cor os scapulo-coracoide, pec-ra pectoral rays, pec-sp pectoral spine of os cleithrum, o-sca-cor os scapulo-coracoide, pec-ra pectoral rays, pec-sp pectoral spine. 
the dorsal surface of the pectoral girdle, originates on the dorso-medial edge of the scapulo-coracoid and inserts on the anterior edge of the dorsal condyle of the pectoral spine.

Musculus adductor superficialis. It is differentiated into two sections. The larger section originates on the posterior surfaces of both the cleithrum and the scapulo-coracoid, as well as on the dorso-lateral edge of the mesocoracoid arch and inserts on the antero-dorsal margin of the dorsal part of the pectoral fin rays. The smaller section runs from the ventrolateral edge of the mesocoracoid arch and the dorsal surface of the proximal radials to the antero-ventral margin of the dorsal part of the pectoral fin rays.

Musculus abductor superficialis. This muscle is also differentiated into two sections. The larger section (Fig. 5: mab-sup-1) runs from the ventral surface of the scapulo-coracoid to the antero-ventral margin of the ventral part of the pectoral fin rays. The smaller section, situated dorsally to the larger one, runs from the postero-lateral edge of the scapulo-coracoid to the antero-dorsal margin of the ventral part of the pectoral fin rays.

Musculus abductor profundus. It originates on the postero-medial edge of the coracoid (Fig. 5), passes anteriorly to the mesocoracoid arch and to the adductor superficialis muscle, and inserts on the medial surface of the dorsal condyle of the pectoral spine.

Musculus protractor pectoralis. This well-developed muscle (Fig. 1) originates on the ventral surfaces of the pterotic, epiocipital and posttemporo-supracleithrum and inserts on the antero-dorsal surface of the cleithrum.

\section{Pangasius larnaudii}

In what concerns the osteological and myological structures of the pectoral girdle and cephalic region described above, there are no significant differences between P. larnaudii and P. macronema.

\section{Helicophagus leptorhynchus and Helicophagus typus}

\section{Osteology}

In a general way, the configuration of the osteological structures of the pectoral girdle and cephalic region of these two species resembles that of $P$. macronema and $P$. larnaudii, with the most significant differences being that in both $H$. leptorhynchus and H. typus: 1 ) the antero-ventro-mesial laminar extensions of the dentary bones are missing; 2) the maxillas are significantly less elongated proximo-distally than those of P. macronema and P. larnaudii; 3 ) there are no dorso-medial concavities of the mesethmoids; 4) the autopalatines exhibit, anterodorsally to their articular surface for the neurocranium, a prominent, dorsally pointed, triangular process; 5) the 'elastic spring apparatus' is missing; 6) the parurohyals are significantly smaller than those of $P$. macronema and P. larnaudii; 7) the additional tooth-plates of the suspensorium are missing.

\section{Myology}

The configuration of the cephalic and pectoral girdle muscles of $H$. leptorhynchus and $H$. typus resembles that of $P$. macronema and $P$. larnaudii, with the principal differences being that in $H$. leptorhynchus and $H$. typus: 1$)$ the larger section of the muscle abductor superficialis, the abductor superficialis 1 , originates not only on the ventral surface of the scapulo-coracoid, but also on a great part of the ventral surface of the cleithrum; 2) the cartilages of the mandibular barbels, lodged on the ventral surface of the pars ventralis of the protractor hyoideus, have a circular shape and contact each other on the mid-line.

\section{DISCUSSION}

The comparison with non-pangasiids pointed out two peculiar, distinct features that are present in the pangasiids examined (i.e. in members of both the two pangasiid genera, Pangasius and Helicophagus) and in no other catfishes examined by the author or described in the literature, which thus could represent pangasiid autapomorphies. These two features are described below. It is important to notice here that the results presented in the present work were supported by a broad cladistic analysis including 440 characters and 87 siluriform terminal from all the extant siluriform families (Diogo, 2004).

Presence of large, roughly circular foramen between the anterodorsomedial surface of the extrascapular, the dorsomesial surface of the pterotic and the dorsolateral surface of the parieto-supraoccipital. Plesiomorphically catfishes lack major concavities or true foramens on the posterodorsal surface of the neurocranium (Chardon; De Pinna, 1996). However, in the pangasiid catfishes examined, there is a large, roughly circular foramen between the anterodorsal surface of the extrascapular, the dorsomesial surface of the pterotic and the dorsolateral surface of the parieto-supraoccipital (Fig. 1). Although some other few catfish groups exhibit, apomorphically, concavities and/or foramens on the posterodorsal surface of the neurocranium, the configuration of pangasiids is unique. Indeed, in most of the non-pangasiid catfishes exhibiting fossae and/or foramens on the posterodorsal surface of the neurocranium, such as e.g. the 
supratemporal fossa of akysids, sisorids, erethistids or aspredinids (see De Pinna, 1996), these fossae and/or foramens do not border the extrascapular. They situate, instead, between the pterotic and the parieto-supraoccipital, between the posttemporo-supracleithrum and the pterotic or between the parieto-supraoccipital and the posttemporo-supracleithrum (see e.g. De Pinna, 1996: Fig. 10). And, in those few catfish groups in which the concavities and/or foramens border the extrascapular, such as e.g. ariids, claroteids or ictalurids, these concavities or foramens situate laterally, and not anteromesialy, to the extrascapular. They are thus situated between this latter bone, the pterotic and the posttemporo-supracleithrum (see e.g. Diogo \& Chardon, 2000a: Fig. 2), and not between it, the pterotic and the parieto-supraoccipital, as it occurs in the pangasiids (Fig. 1).

Presence of a prominent, elongated crest on the dorso-lateral surfaces of both the hyomandibulo-metapterygoid and the ento-ectopterygoid. This character was first proposed by Vidthayanon (1992), but, since this is an unpublished Doctoral thesis, it has been mainly ignored in catfish literature (see e.g. Teugels). However, the author's observations and comparisons pointed out that this character indeed seems to constitute a pangasiid autapomorphy. Usually in catfishes there are no major dorsal crests on the dorso-lateral surface of the suspensorium, or these crests, if present, are restricted to the hyomandibulo-metapterygoid. However, in the pangasiids examined, and exclusively in these catfishes, there is a prominent, elongated dorsal crest formed by the dorso-lateral surfaces of both the hyomandibulo-metapterygoid and the entoectopterygoid (Fig. 3).

In addition to these two features, one other feature, although not exclusively present in pangasiid catfishes, could constitute a Pangasiidae synapomorphy:

Elongation of coronoid process of mandible. Plesiomorphically in catfishes the coronoid process of the mandible is not significantly elongated anteroposteriorly, embracing just a small portion of the posterodorsal surface of the dentary bone (Mo). However, in claroteins (see e.g. Mo, 1991: Fig. 38), as well as in the pangasiids examined (Fig. 1), the coronoid process is markedly elongated anteroposteriorly, extending anteriorly far beyond the anguloarticular/dentary suture at the level of this process and, thus, embracing a significant portion of the posterodorsal surface of the dentary bone. As this derived structure is only found in the clarotein and pangasiid catfishes, and as claroteines appear to be more closely related to other catfish groups (e.g. auchenoglanidines, ariids, austroglanidids and cranoglanidids) than to pangasiids (Mo; De Pinna, 1998; Diogo et al., 2002a; Diogo, 2003ab, 2004), this feature was seemingly independently acquired in these two groups.
With respect to the phylogenetic relationships of the Pangasiidae, most of the authors consider this family to be the sister-group of the Schilbidae (see e.g. Teugels, 2003; De Pinna, 1998), but no reliable synapomorphies have been proposed in previous published studies to support such a sister-group relationship. Some authors, such as e.g. Regan (1911) or Chardon (1968), consider, alternatively, that the pangasiids could be more closely related to the bagrids than to schilbids. The analysis promoted by the author of the present study corroborates the sister-group relationship between the Schilbidae and Pangasiidae. Two peculiar, synapomorphic features support this sister-group relationship:

Presence of a large foramen between dorsal surfaces of the frontal and the lateral ethmoid. In some catfishes, as e.g. in the silurids, cranoglanidids, ictalurids and doradids, as well as in part of the mochokids (Synodontis) and auchenipterids (Ageneiosus) examined, there is a groove, or a fossa, between the dorsal surfaces of the frontal and the lateral ethmoid. However, a complete perforation of the dorsal surface of the neurocranium by a true, large foramen between the frontal and the lateral ethmoid is a feature only found in the pangasiid, schilbid and ariid catfishes examined. As the Ariidae are seemingly more closely related to other catfish groups (e.g. Claroteidae, Austroglanididae, Cranoglanididae and Ictaluridae: Diogo et al., 2002a; Oliveira et al., 2002; Diogo, 2003a; Diogo, 2004) than to the Schilbidae and the Pangasiidae, this feature was probably independently acquired in the Ariidae, thus constituting a synapomorphy to support the clade Schilbidae + Pangasiidae.

Anterior margin of cartilages associated with mandibular barbels somewhat bifurcated, presenting two anterolateral arms. Usually in catfishes the cartilages associated with the mandibular barbels, when present, are not bifurcated anteriorly (Diogo \& Chardon, 2000c). However, in the schilbid and pangasiid catfishes examined, these cartilages are somewhat bifurcated anteriorly, exhibiting two more or less distinguished antero-lateral arms (Fig. 4). Among all the siluriforms examined by the author and described in the literature, this feature is only found in these two groups, thus supporting their sister-group relationship. In fact, as noted De Pinna (1998), the uniform, exclusive presence of a well-defined, distinct feature in a certain catfish clade is extremely rare in a taxon as large and diverse as the Siluriformes. As other studies recently published by the author and colleagues (e.g. Diogo et al., 1999, 2000a,b, 2001c, 2002a,b; Diogo \& Chardon, 2000c; Oliveira et al., 2001; Diogo, $2003 \mathrm{~b}$ ), the present work thus stresses that the analysis of certain characters that are not usually included in the study of catfish relationships, such as e.g. those concerning precisely the configuration of the structures associated with the mandibular barbels or of the cephalic muscles could reveal useful data to infer the phylogeny of these fishes. 
ACKNOWLEDGEMENTS: I thank J. Cambray (Albany Museum of Grahamstown), G.G. Teugels (Musée Royal de l'Afrique Centrale), P. Laleyé (Université Nationale du Bénin), R. Vari, J. Williams and S. Jewett (National Museum of Natural History) and P. Duhamel (Muséum National D'Histoire Naturelle) for kindly providing a large part of the catfishes studied during the last years. I would also like to acknowledge I. Doadrio, I. Peng, G.G. Teugels, R.P. Vari, S. Weitzman, T. Abreu, A. Zanata, B.G. Kapoor, F. Meunier, S.
He, D. Adriaens, F. Wagemans, C. Oliveira, E. Parmentier, M.M. de Pinna, P. Skelton, M.J.L. Stiassny, F.J. Poyato-Ariza, G. Arratia, T. Grande, M.G., H. Gebhardt, M. Ebach, A. Wyss, J. Waters, B. Perez-Moreno, G. Cuny, A. Choudhury, M. Vences, S.H. Weitzman, L. Cavin, F. Santini, J.C. Briggs, L.M. Gahagan, Philiphe J.G. Maisey, M. Gayet, J. AlvesGomes, G. Lecointre, C. Borden, L. Taverne, P. Vandewalle and M. Chardon for their helpful discussions, criticism, advice and assistance.

DIOGO, R. Osteología y miología de la región cefálica y de la cintura pectoral del Pangasius macronema, con una discusión de las sinapomorfías y relaciones filogenéticas de los Pangasiidae (Telostei: Siluriformes). Int. J. Morphol., 25(3):453-466, 2007.

RESUMEN: Se describen las estructuras cefálicas y la cintura pectoral del Pangasius macronema y son comparadas con las de otros representantes del mismo género, Pangasius larnaudii, y las de otros Pangásidos, Helicophagus leptorhynchus y Helicophagus typus, así como de varios otros peces gato, como base para la discusión de las sinapomorfías y relaciones filogenéticas de los Pangásidos. Las siguientes dos características constituyen autapomorfías de los Pangásidos: 1) Presencia de una cresta prominente sobre la cara dorsolateral del hueso hyomandíbulo-metapterigoídeo y el hueso entopterigoídeo. 2) Presencia de un amplio foramen circular entre la superficie anterodorsomedial del hueso extracapsular, la cara dorsomedial del hueso pterótico y la cara dorsolateral del hueso parietosupraoccipital. Con respecto a las relaciones filogenéticas de los Pangásidos, esta familia está aparentemente relacionada a la familia Schilbidae.

PALABRAS ClAVE: Pez gato; Helicophagus; Pangasius; Sinapomorfías Pangasiidae; Morfología; Filogenia; Siluriformes.

\section{REFERENCES}

Alexander, R. M. Structure and function in catfish. J. Zool. (Lond.), 148:88-152, 1965.

Bhimachar, B. S. On the morphology of the skull of certain Indian catfishes. J. Mysore Univ., 7:233-67, 1933.

Bridge, T. W. \& Haddon, A.C. Contributions to the anatomy of fishes, II - The air-bladder and Weberian ossicles in the siluroid fishes. Phil. Trans. R. Soc. Lond. (B), 184:65333, 1894.

Chardon, M. Anatomie comparée de l'appareil de Weber et des structures connexes chez les Siluriformes. Ann. Mus. R. Afr. Centr., 169:1-273, 1968.

De Pinna, M. C. C. A phylogenetic analysis of the Asian catfish families Sisoridae, Akysidae and Amblycipitidae, with a hypothesis on the relationships of the Neotropical Asprenidae (Teleostei, Ostariophysi). Fieldiana (Zool.), 84:1-82, 1996.

De Pinna, M. C. C. Phylogenetic relationships of Neotropical siluriformes: History overview and synthesis of hypotheses. In Malabarba, L. R.; Reis, R. E.; Vari, R. P.; Lucena, Z. M. \& Lucena, C. A. S. eds. Phylogeny and Classification of Neotropical Fishes. Porto Alegre, Edipucrs, pp. 279-330, 1998.
Diogo, R. Higher-level phylogeny of Siluriformes: an overview. In Arratia, G; Kappor, B. G.; Chardon, M. \& Diogo, R. eds. Catfishes. Enfield, Science Publishers, pp. 353-84, 2003a.

Diogo, R. Anatomy, phylogeny and taxonomy of Amphiliidae. In Arratia, G.; Kappor, B. G.; Chardon, M. \& Diogo, R. eds. Catfishes. Enfield, Science Publishers, pp. 401-38, 2003b.

Diogo, R. Morphological evolution, aptations, homoplasies, constraints, and evolutionary trends: catfishes as a case study on general phylogeny and macroevolution. Enfield, Science Publishers, 2004.

Diogo, R. \& Chardon, M. Anatomie et fonction des structures céphaliques associées á la prise de nourriture chez le genre Chrysichthys (Teleostei: Siluriformes). Belg. J. Zool., 130:21-37, 2000a.

Diogo, R. \& Chardon, M. Homologies Between Different Adductor Mandibulae Sections of Teleostean Fishes, with a Special Regard to Catfishes (Teleostei: Siluriformes). J. Morphol., 243:193-208, 2000b.

Diogo, R. \& Chardon, M. The structures associated with catfish (Teleostei: Siluriformes) mandibular barbels: 
DIOGO, R. Osteology and myology of the cephalic region and pectoral girdle of Pangasius macronema, with a discussion on the synapomorphies and phylogenetic relationships of the Pangasiidae (Telostei: Siluriformes). Int. J. Morphol., 25(3):453-466, 2007.

Origin, Anatomy, Function, Taxonomic distribution, Nomenclature and Synonymy. Neth. J. Zool., 50:455$78,2000 \mathrm{c}$.

Diogo, R. \& Chardon, M. Homologies and evolutionary transformation of the skeletal elements of catfish (Teleostei: Siluriformes) suspensorium: a morphofunctional hypothesis. In Val, A. L. \& Kapoor, B. G. eds. Fish adaptations. Enfield, Science Publishers, pp. 275-284, 2003.

Diogo, R. \& Vandewalle, P. Review of superficial cranial musculature of catfishes, with comments on plesiomorphic states. In Arratia, G.; Kappor, B. G.; Chardon, M. \& Diogo, R. eds. Catfishes. Enfield, Science Publishers, pp. 47-69, 2003.

Diogo, R.; Vandewalle, P. \& Chardon, M. Morphological description of the cephalic region of Bagrus docmak, with a reflection on Bagridae (Teleostei: Siluriformes) autapomorphies. Neth. J. Zool., 49:207-32, 1999.

Diogo, R; Oliveira, C. \& Chardon, M. The origin and transformation of catfish palatine-maxillary system: an example of adaptive macroevolution. Neth. J. Zool., 50:373-88, 2000a.

Diogo, R; Oliveira, C. \& Chardon, M. On the anatomy and function of the cephalic structures in Phractura (Siluriformes: Amphiliidae), with comments on some striking homoplasies occuring between the doumeins and some loricaroid catfishes. Belg. J. Zool., 130:117-30, 2000b.

Diogo, R; Oliveira, C. \& Chardon, M. On the homologies of the skeletal components of catfish (Teleostei: Siluriformes) suspensorium. Belg. J. Zool., 131:155-71, 2001a.

Diogo, R; Oliveira, C. \& Chardon, M. On the osteology and myology of catfish pectoral girdle, with a reflection on catfish (Teleostei: Siluriformes) plesiomorphies. J. Morphol., 249:100-25, 2001 b.

Diogo, R; Oliveira, C. \& Chardon, M. Osteology and myology of the cephalic region and pectoral girdle of Bunocephalus knerii, and a discussion on the phylogenetic relationships of the Aspredinidae (Teleostei: Siluriformes). Neth. J. Zool., 51:457-81, 2001c.

Diogo, R; Oliveira, C. \& Chardon, M. Osteology and myology of the cephalic region and pectoral girdle of the Chinese catfish Cranoglanis bouderius, with a discussion on the autapomorphies and phylogenetic relationships of the Cranoglanididae (Teleostei: Siluriformes). J. Morphol., 253:229-42, 2002a.

Diogo, R; Oliveira, C. \& Chardon, M. Osteology and myology of the cephalic region and pectoral girdle of Glyptothorax fukiensis (Rendahl, 1925), comparison with other sisorids, and comments on the synapomorphies of the Sisoridae (Teleostei: Siluriformes). Belg. J. Zool., 132:93-101, 2002b.

Diogo, R; Vandewalle, P. \& Chardon, M. On the osteology and myology of the cephalic region and pectoral girdle of Chaca bankanensis Bleeker 1852, with comments on the autapomoprhies and phylogenetic relationships of the Chacidae (Teleostei: Siluriformes). Anim. Biol., 54:159-74, 2004a.

Diogo, R; Vandewalle, P. \& Chardon, M. On the osteology and myology of the cephalic region and pectoral girdle of Franciscodoras marmoratus (Lütken 1874), comparison with other doradids, and comments on the synapomorphies and phylogenetic relationships of the Doradidae (Teleostei: Siluriformes). Anim. Biol., 54:17593, 2004b.

Diogo, R; Vandewalle, P. \& Chardon, M. Osteology and myology of the cephalic region and pectoral girdle of Schilbe mystus and comparison with other schilbids, with comments on the monophyly and phylogenetic relationships of the Schilbidae (Teleostei: Siluriformes). Anim. Biol., 54:91-110, 2004c.

Ferraris, C. J. \& De Pinna, M. C. C. Higher-level names for Catfishes (Actinopterygii: Ostariophysi: Siluriformes). Proc. Calif. Acad. Sci., 51:1-17, 1999.

Gauba, R. K. The endoskeleton of Nagarius bagarius (Ham), part I - The skull. Agra Univ. J. Res., 11:75-90, 1962.

Gauba, R. K. Studies on the osteology of Indian sisorid catfishes, II The skull of Glyptothorax cavia. Copeia, 4:802-10, 1966.

Gauba, R. K. Studies on the skull of the Indian Sisorid catfish, Erethistes pussilus. J. Zool. (Lond.), 151:379-88, 1967.

Gauba, R. K. On the morphology of the skull of catfish Pseudecheneis sulcatus. Zool. Anz., 181:226-36, 1968.

Gauba, R. K. The head skeleton of Glyptosternum reticulatum McClelland and Grifith. Monit. Zool. Ital., 3:1-17, 1969. 
DIOGO, R. Osteology and myology of the cephalic region and pectoral girdle of Pangasius macronema, with a discussion on the synapomorphies and phylogenetic relationships of the Pangasiidae (Telostei: Siluriformes). Int. J. Morphol., 25(3):453-466, 2007.

Gosline, W. A. The palatine-maxillary mechanism in catfishes with comments on the evolution and zoogeography of modern siluroids. Occ. Pap. Calif. Acad. Sci., 120:1-31, 1975.

Gustiano, R.; Teugels, G. G. \& Pouyaud, L. Revision of the Pangasius kunyit catfish complex, with description of two new species from southeast Asia (Siluriformes, Pangasiidae). J. Nat. Hist., 37:357-76, 2003.

Howes, G. J. Problems in catfish anatomy and phylogeny exemplified by the Neotropical Hypophthalmidae (Teleostei Siluroidei). Bull. Br. Mus. Nat. Hist. (Zool.), 45:1-39, 1983a.

Howes, G. J. The cranial muscles of the loricarioid catfishes, their homologies and value as taxonomic characters. Bull. Br. Mus. Nat. Hist. (Zool.), 45:309-45, 1983 b.

Howes, G. J. The phylogenetic relationships of the electric family Malapteruridae (Teleostei: Siluroidei). J. Nat. Hist., 19:37-67, 1985.

McMurrich, J. P. On the osteology of Amiurus catus (L) Gill. Zool. Anz. 168:296-99, 1884.

Mo, T. Anatomy, relationships and systematics of the Bagridae (Teleostei: Siluroidei) with a hypothesis of siluroid phylogeny. Theses Zoologicae, 17:1-216, 1991.

$\mathrm{Ng}, \mathrm{H}$. H. \& Kottelat, M. Helicophagus leptorhynchus, a new species of molluscivorous catfish from Indochina (Teleostei: Pangasiidae). Raffles Bull. Zool., 48:55-8, 2000.

Oliveira, C.; Diogo, R.; Vandewalle, P. \& Chardon, M. On the myology of the cephalic region and pectoral girdle of three ariid species, Arius heudeloti, Genidens genidens and Bagre marinus, and comparison with other catfishes (Teleostei: Siluriformes). Belg. J. Zool., 132:17-24, 2002.

Pouyaud, L. \& Teugels, G.G. Description of a new pangasiid catfish from East Kalimantan, Indonesia (Siluriformes, Pangasiidae). Ichthyol. Explor. Fresh., 11:193-200, 2000.

Pouyaud, L.; Teugels, G. G. \& Legendre, M. Description of a new pangasiid catfish from South-East Asia (Siluriformes, Pangasiidae). Cybium, 23:247-58, 1999.

Pouyaud, L.; Teugels, G. G.; Gustiano, R. \& Legendre, M. Contribution to the phylogeny of pangasiid catfishes (Siluriformes, Pangasiidae) based on allozymes and mitochondrial DNA. J. Fish. Biol., 56:1509-38, 2000.
Regan, C. T. The classification of the teleostean fishes of the order Ostariophysi - 2 Siluroidea. Ann. Mag. Nat. Hist., 8:553-77, 1911.

Roberts, T. R. \& Vidthayanon, C. Systematic revision of the Asian catfish family Pangasiidae, with biological observations and descriptions of three new species. Proc. Acad. Nat. Sci. Philad., 143:97-144, 1991.

Taylor, W. R. \& Van Dyke, G. C. Revised procedures for staining and clearing small fishes and other vertebrates for bone and cartilage study. Cybium, 9:107-19, 1985.

Teugels, G. G. State of the art of recent siluriform systematics. In Arratia, G.; Kappor, B. G.; Chardon, M. \& Diogo, R. eds. Catfishes. Enfield, Science Publishers, pp. 317-52, 2003.

Tilak, R. The osteocranium and the Weberian apparatus of the fishes of the family Sisoridae (Siluroidea): a study in adaptation and taxonomy. Zeitsch. Wissensch. Zool., 169:281-320, 1963a.

Tilak, R. Studies on the nematognathine pectoral girdle in relation to taxonomy. Ann. Mag. Nat. Hist., 13:145-55, $1963 \mathrm{~b}$.

Tilak, R. The osteocranium and Weberian apparatus of the family Schilbeidae. Proc. Zool. Soc. Lond., 143:1-36, 1964.

Vidthayanon, C. Taxonomic revision of the catfish family Pangasiidae. Unpublished PhD thesis, Tokyo University of Fisheries, 1992.

Correspondence to:

Dr. Rui Diogo,

Department of Anthropology

The George Washington University

2110 G St. NW

Washington, DC 20052

USA

Email: R.Diogo@ulg.ac.be

Received: 06-04-2006

Accepted: 10-05-2007 